\title{
WATER USE EFFICIENCY OF WHEAT AS AFFECTED BY AGROCLIMATE IN QANTRA, EGYPT
}

\author{
A. Sadik ${ }^{1} *$, A. Abdel-Aziz ${ }^{2}$
}

\section{ABSTRACT}

Wheat is one of the most important strategic crops in Egypt. It is noted in the recent period that the productivity of wheat in some areas of Egypt has been affected significantly by climate change so it must be overcome them by changing the planting dates and use wheat varieties suitable for each region. This experiment was carried out in El-Qantara Sharq area, Ismailia governorate, Egypt, during the winter seasons of 2014/2015and 2015/2016, at a private farm to study the effect of three applied irrigation water levels $\left(I R_{100,85,70 \%}\right)$, four planting date (PD) $\left(15^{\text {th }}\right.$ October, $1^{\text {th }}$ November, $15^{\text {th }}$ November, $30^{\text {th }}$ November) and three wheat varieties $(V)$ (Sakha 94, Gemmiza 7 and Misr 2) on yield production, crop quality parameters, actual evapotranspiration (ETa), water use efficacy (WUE) and irrigation water use efficiency (IWUE) for wheat bread (Triticum aestivum L.). The experimental design was a split-split plot design with three replicates. The results showed that, the studied quality parameters and yield production for wheat gave the highest values under IR=100\%, $P D=15^{\text {th }}$ Nov. and Misr 2 variety treatment for both seasons. While, ETa gave the lowest values 167.67 and $161.43 \mathrm{~mm}$ for both seasons respectively, under $I R=70 \%, P D=15^{\text {th }}$ Oct. and Misr 2 variety treatment. Moreover, the maximum values of wheat WUE and IWUE were 3.08 and $1.56 \mathrm{~kg} / \mathrm{m}^{3} ; 3.27$ and $1.59 \mathrm{~kg} / \mathrm{m}^{3}$ for both seasons respectively, under $I R=70 \%, P D=1^{\text {th }}$ Nov. and Misr 2 variety treatment. This study concluded that the cultivation of wheat variety Misr 2 early on $1^{\text {th }}$ Nov. under IR $=70 \%$ could be saved about $37 \%$ of added irrigation water versus yield reduction of wheat about 8 and $10 \%$ for both seasons respectively, compared to the control treatment $\left(P D=100 \%\right.$ and $15^{\text {th }}$ Nov).

Kye words: Planting date; Wheat varieties; Water use efficiency; Irrigation water use efficiency.

\footnotetext{
1 and 2 Researcher of water requirement unite, Soil Chemistry and Physics Dept., DRC, Cairo, Egypt.
} 


\section{INTRODUCTION}

$\mathrm{W}$ heat is one of the major grain crops in the world. The crop is firstly cultivated for its cereals, which is used by human in his food. Wheat is also the major grain crop of Egypt and stock for about $40.2 \%$ of the total grain production with acreage of 1.26 million hectares (Anonymous 2010).

The planting date has a significant impact on the productivity of wheat grains by affecting the development and survival of tillers. The perfect wheat planting date is up to $15^{\text {th }}$ November, while the planting process is finished at the end of November and the first two weeks of December.

Early wheat cultivation gave the highest yields of grain similar results were, more or less obtained by Qamar et al. (2004), Jalota et al. (2010), Khokhar et al. (2010), El-Kalla et al. (2010), Amin et al. (2011) and Seleiman et al. (2011).

Lak et al. (2013) showed that the maximum grain yield of 10.15 ton/ha were recorded by planting wheat on 15 th November. While, the minimum grain yield of 6.1 ton/ha were recorded by planting wheat on 30th December.

Yassin and Kittani (2009) stated that no significant differences in the effect of wheat varieties or interaction between wheat varieties and planting dates. While, planting date had an extremely significant impact on grain yield and harvest index. Wheat cultivation on the start of November gave the highest grain yield 2.48 ton/ha, stalk yield 2.203 ton/ha and harvest index $23.27 \%$.

Ouda et al. (2005) reported that, planting wheat in Oct. reduced grain yield by about $10 \%$. While, lateness of planting date till the end of December decreased yield by about $16 \%$.

Haroun et al. (2012) and Fazal et al. (2015) showed that the control planting date $20^{\text {th }}$ Nov. override the other planting dates in all yield studied parameters and flour quality. While, delayed planting date $15^{\text {th }}$ Dec. lead to an increase in flour quality (protein, wet and dry gluten) of the grain yield.

Seleem and Abd El Dayem (2013) Reported that the maximum significant value of grain yield was set by Gemmeiza 9 followed by Misr 
2 then Sakha 94 and Giza 168. While, the minimum value were observed when planting of Sakha 94 variety.

Moussa and Abdel Maksoud (2004) stated that the number of spikes $/ \mathrm{m}^{2}$, 1000-grain weight, straw and grain yields decreased due to irrigation after higher soil moisture depletion.

Khalil et al. (2005) and EL Afandi et al. (2010) concluded that the irrigating wheat at 1.2 evaporation pan coefficient (EPC) in Upper Egypt (Shandaweel) recorded the highest actual evapotranspiration (ETa) in comparison with 0.8 and 1.0 EPC, with ETa values of 1582, 1797 and $2216 \mathrm{~m}^{3} / \mathrm{fed}$, for irrigation treatments at $0.8,1.0$ and $1.2 \mathrm{EPC}$, respectively, however $0.8 \mathrm{EPC}$ gave the highest water use efficiency.

Salem et al. (2006) and Poraas et al. (2010) concluded that for (Delta region of Egypt Bahteem) ETa and WUE for wheat were highest with 1.2 EPC more than either 0.8 or 1.0 EPC with respect to crop productivity as a function for soil moisture availability during the growing season.

This study aimed to investigate the effect of applied irrigation water levels, planting date and wheat varieties on crop production, quality growth parameters, actual evapotranspiration, water use efficiency and irrigation water use efficiency.

\section{MATERIALS AND METHODS}

\section{1- Experiments:}

Field experiments were carried out in El-Qantara Sharq area, Ismailia governorate, Egypt at ( $30^{\circ} 54^{\prime} 36^{\prime} \mathrm{N}$ : $32^{\circ} 12^{`} 36^{\prime} \mathrm{E} .5 \mathrm{~m}$ a.s.1), during the winter seasons of 2014/2015 and 2015/2016. In split-split plot design with three replicates, the experimental was divided into $40 \mathrm{~m}^{2}(5 \times 8 \mathrm{~m})$ plots; each bounded by $1.5 \mathrm{~m}$ wide barren to avoid horizontal seepage. The obtained data were subjected to statistical analysis according to Snedecor and Cochran (1989) using Co-state software program. Cultivate three varieties of wheat Triticum aestivum L. Sakha 94, Gemmiza7 and Misr 2 by using four planting date PD $15^{\text {th }}$ October, $1^{\text {th }}$ November, $15^{\text {th }}$ November, $30^{\text {th }}$ November and three applied irrigation water IR100, 85 and $70 \%$ of crop evapotranspiration added by using sprinkler irrigation system (Fig. 1). 
Plant height $(\mathrm{PH}) \mathrm{cm}$, numbers of spikes (NS) spikes $/ \mathrm{m}^{2}, 1000$ grain weight $(\mathrm{GW}) \mathrm{g}$, grain crude protein content (GCP) \%, gluten content (GC) \%, harvest index (HI) \%, total yield (TY) $\mathrm{Mg} / \mathrm{ha}$, straw yield (SY) $\mathrm{Mg} / \mathrm{ha}$ and grain yield (GY) $\mathrm{Mg} / \mathrm{ha}$ were determined for wheat varieties. Actual evapotranspiration ETa $(\mathrm{mm})$, water use efficiency WUE $\left(\mathrm{kg} / \mathrm{m}^{3}\right)$ and irrigation water use efficiency IWUE $\left(\mathrm{kg} / \mathrm{m}^{3}\right)$ were calculated at different planting date (PD) and applied irrigation water (IR) for all wheat varieties plots.

\section{Soil characteristics:}

Soil samples were collected for some physical and chemical characteristics of soil. The methodological procedures were according to methods described by Page et al. (1982) and Klute (1986). (Tables $1 \& 2)$.

Table (1): Some physical characteristics of experimented soil

\begin{tabular}{|c|c|c|c|c|c|c|c|c|c|c|c|c|}
\hline \multirow{2}{*}{$\begin{array}{c}\text { Soil } \\
\text { depth } \\
\text { (cm) }\end{array}$} & \multicolumn{5}{|c|}{ Particle size distribution \% } & \multirow[b]{2}{*}{$\begin{array}{l}\text { Textural } \\
\text { class }\end{array}$} & \multirow[b]{2}{*}{$\underset{\%}{\mathrm{OM}}$} & \multirow[b]{2}{*}{$\begin{array}{c}\rho_{b} \\
\mathrm{~g} / \mathrm{cm}^{3}\end{array}$} & \multirow{2}{*}{$\begin{array}{c}\mathrm{Ks} \\
\mathbf{c m} / \mathbf{h}\end{array}$} & \multirow[b]{2}{*}{$\begin{array}{c}\text { FC } \\
\%\end{array}$} & \multirow{2}{*}{$\begin{array}{l}\text { WP } \\
\%\end{array}$} & \multirow[b]{2}{*}{$\underset{\%}{\mathrm{AW}}$} \\
\hline & $\begin{array}{c}\text { C. } \\
\text { sand }\end{array}$ & $\begin{array}{l}\text { M. } \\
\text { sand }\end{array}$ & $\begin{array}{c}\text { F. } \\
\text { sand }\end{array}$ & Silt & Clay & & & & & & & \\
\hline $0-20$ & 54.15 & 8.47 & 31.73 & 3.29 & 2.36 & S & 0.49 & 1.53 & 13.35 & 12.43 & 4.70 & 7.73 \\
\hline $20-40$ & 54.83 & 7.65 & 32.07 & 3.11 & 2.34 & $S$ & 0.42 & 1.56 & 14.19 & 11.98 & 4.53 & 7.45 \\
\hline $40-60$ & 55.37 & 7.19 & 32.61 & 2.85 & 1.98 & $S$ & 0.28 & 1.61 & 14.27 & 11.51 & 4.23 & 7.28 \\
\hline
\end{tabular}

Table (2): Some chemical characteristics of experimented soil

\begin{tabular}{|c|c|c|c|c|c|c|c|c|c|c|c|c|}
\hline \multirow{2}{*}{ 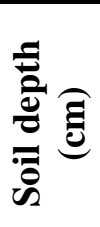 } & \multirow{2}{*}{ 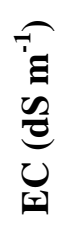 } & \multirow[b]{2}{*}{$\frac{\pi}{2}$} & \multirow{2}{*}{ 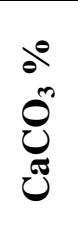 } & \multirow{2}{*}{ نَّ } & \multicolumn{8}{|c|}{ Soluble ions $(\mathrm{meq} / \mathrm{l})$ in the saturated soil paste extract } \\
\hline & & & & & z & \pm & שֶ & $\sum_{i=1}^{+\infty 00}$ & $\bar{\nu}$ & 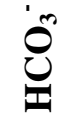 & ê & Oे \\
\hline $0-2$ & 2.76 & 78 & 478 & 726 & 3.54 & 2.21 & 6.56 & 5.2 & 13 & 38 & & 10.69 \\
\hline 20-40 & 93 & 7.67 & 3.72 & 6.81 & 12.97 & 3.43 & 7.39 & 5.51 & 13.89 & 3.67 & - & 11.74 \\
\hline $40-60$ & 3.41 & 7.53 & 3.65 & 6.59 & 11.81 & 4.69 & 10.13 & 7.47 & 16.2 & 3.59 & - & 14.31 \\
\hline
\end{tabular}

\section{Quality of irrigation water:}

Chemical analyses of the irrigation water were measured according to methods described by Ayers and Westcot (1994). (Table 3). 
Table (3): Some chemical analysis for irrigation water

\begin{tabular}{|c|c|c|c|c|c|c|c|c|c|c|c|}
\hline \multirow[b]{2}{*}{ Sample } & \multirow[b]{2}{*}{ pH } & \multirow{2}{*}{$\begin{array}{c}\text { EC } \\
\text { dS } \mathbf{m}^{-1}\end{array}$} & \multirow{2}{*}{ SAR } & \multicolumn{4}{|c|}{ ــ Solublecations meal } & \multicolumn{4}{|c|}{ Lلـ Soluble_anions mea } \\
\hline & & & & $\mathrm{Na}^{+}$ & $\mathbf{K}^{+}$ & $\mathbf{C a}^{++}$ & $\mathbf{M g}^{++}$ & $\mathbf{C L}^{-}$ & $\mathrm{HCO}_{3}$ & $\mathrm{CO}_{3}{ }^{=}$ & $\mathrm{SO}_{4}{ }^{=}$ \\
\hline Mean & 7.87 & 1.94 & 3.68 & 7.58 & 3.32 & 4.86 & 3.64 & 4.73 & 7.21 & - & 7.46 \\
\hline
\end{tabular}

\begin{tabular}{|c|c|c|c|}
\hline$P D=30$ Nov. & $P D=1$ Nov. & $P D=15$ Nov. & $\mathrm{PD}=15$ Oct. \\
\hline Misr 2 & Sakha 94 & Misr 2 & Gemmiza7 \\
\hline Gemmiza7 & Gemmiza7 & Sakha 94 & Misr 2 \\
\hline Sakha 94 & Misr 2 & Gemmiza7 & Sakha 94 \\
\hline$P D=15$ Nov. & $P D=15$ Oct. & $P D=30$ Nov. & $P D=1$ Nov. \\
\hline Gemmiza7 & Sakha 93 & Gemmiza7 & Sakha 94 \\
\hline Sakha 94 & Misr 2 & Misr 2 & Gemmiza7 \\
\hline Misr 2 & Gemmiza7 & Sakha 94 & Misr 2 \\
\hline$P D=15$ Oct. & $P D=15$ Nov. & $P D=1$ Nov. & $P D=30$ Nov. \\
\hline Sakha 4 & Misr 2 & Sakha 94 & Misr 2 \\
\hline Misr 2 & Sakha 94 & Gemmiza7 & Sakha 94 \\
\hline Gemmiza7 & Gemmiza7 & Misr 2 & Gemmiza7 \\
\hline
\end{tabular}

Fig. (1): Field experiment layout of El-Qantara Sharq area.

\section{Reference evapotranspiration ETo:}

The reference evapotranspiration ETo) shown in table (4) was calculated by using Penman-Monteith equation FAO 56 method (Allen et al., 1998).

Table (4): Calculation reference evapotranspiration ( $\mathrm{mm} / \mathrm{day}$ ) through Wheat growth period.

\begin{tabular}{ccccccccc}
\hline Month & Oct & Nov & Dec & Jan & Feb & Mar & Apr & May \\
\hline${\text { ETo, } \text { mm day }^{-1}}^{-1}$ & 4.44 & 2.84 & 2.30 & 2.65 & 3.44 & 4.61 & 5.91 & 6.85 \\
\hline
\end{tabular}

\section{Crop evapotranspiration ETc:}

The crop evapotranspiration ETc shown in table (5) was calculated by using the equation:
- $\mathrm{ETc}=\mathrm{Kc}_{\mathrm{FAO}}$. ETo
(mm/day)
(Allen et al., 1998)

Where: $\mathbf{K c}_{\mathrm{FAO}}$ : crop coefficient from FAO No.(56).

ETo : reference crop evapotranspiration, $\mathrm{mm} /$ day. 
Table (5): Calculation crop evapotranspiration ( $\mathrm{mm} / \mathrm{day})$ through wheat growth period.

\begin{tabular}{|c|c|c|c|c|c|c|}
\hline \multirow{3}{*}{ Planting date } & Stages & Initial & Develop. & Mid & Late & Seasonal \\
\hline & \multirow{2}{*}{$\begin{array}{c}\text { Period length (day) } \\
\mathrm{Kc}_{\mathrm{FAO}}(-) \\
\end{array}$} & 20 & 50 & 60 & 30 & 160 \\
\hline & & 0.30 & 0.73 & 1.15 & 0.30 & ------- \\
\hline \multirow{4}{*}{$\begin{array}{l}15^{\text {th }} \text { Oct. } \\
1^{\text {th }} \text { Nov. } \\
15^{\text {th }} \text { Nov. } \\
30^{\text {th }} \text { Nov. }\end{array}$} & \multirow{4}{*}{ ETo $(\mathbf{m m})$} & 82.40 & 129.04 & 173.93 & 131.28 & 516.65 \\
\hline & & 56.80 & 123.55 & 200.72 & 150.00 & 531.07 \\
\hline & & 54.10 & 123.40 & 230.12 & 169.50 & 577.12 \\
\hline & & 46.00 & 134.97 & 264.90 & 185.76 & 631.63 \\
\hline \multirow{4}{*}{$\begin{array}{l}15^{\text {th }} \text { Oct. } \\
1^{\text {th }} \text { Nov. } \\
15^{\text {th }} \text { Nov. } \\
30^{\text {th }} \text { Nov. }\end{array}$} & \multirow{4}{*}{$\mathbf{E T c}_{100 \%}(\mathbf{m m})$} & 24.72 & 94.20 & 200.02 & 39.38 & 358.32 \\
\hline & & 17.04 & 90.19 & 230.83 & 45.00 & 383.06 \\
\hline & & 16.23 & 90.08 & 264.64 & 50.85 & 421.80 \\
\hline & & 13.80 & 98.53 & 304.64 & 55.73 & 472.70 \\
\hline \multirow{4}{*}{$\begin{array}{l}\text { 15thOct. } \\
\text { 1thNov. } \\
\text { 15thNov. } \\
\text { 30thNov. }\end{array}$} & \multirow{4}{*}{ Rainfall (mm) } & 2.10 & 13.60 & 18.30 & 7.90 & 41.90 \\
\hline & & 5.10 & 11.70 & 20.20 & 5.50 & 42.50 \\
\hline & & 4.50 & 15.60 & 15.90 & 4.50 & 40.50 \\
\hline & & 3.20 & 15.80 & 14.70 & 3.70 & 37.40 \\
\hline
\end{tabular}

\section{Leaching requirement $L R$ :}

The leaching requirement LR was calculated by using the equation:
- $\mathbf{L R}=\mathbf{E C}_{\mathrm{w}} /\left(\mathbf{5}\left(\mathrm{EC}_{\mathrm{e}}\right)-\mathrm{EC}_{\mathrm{w}}\right) \times \mathbf{1 0 0}$
(\%)
(Allen et al., 1998)

Where: ECw : electrical conductivity of the irrigation water, $\mathrm{dS} / \mathrm{m}$.

ECe : average electrical conductivity of the soil solution extract, $\mathrm{dS} / \mathrm{m}$.

\section{Deficit irrigation water DI during growth stages:}

The defect irrigation water at each growth stages based on amounts of applied irrigation water (IR) at different planting date for wheat varieties shown in table (6) were calculated by using the equation:

- $\left.\mathrm{IR}_{100,85,70 \%}=(\mathrm{ETc}-\mathrm{pe}) \mathrm{Kr} / \mathrm{Ea}\right)+\mathrm{LR}$

(mm/period)

\section{Keller and Karmeli (1974)}

Where: $\mathbf{K r}$ :correction factor for limited wetting at carrot percent round coverage by canopy $80 \%, \mathrm{Kr}=0.90$. (Smith, 1992).

Ea : irrigation efficiency for sprinkler (70\%) (Allen et al., 1998).

Pe : effective rainfall, $\mathrm{mm} /$ period.

LR : leaching requirements, under salinity levels of irrigation water $(0.15 \times \mathrm{ETc}), \mathrm{mm}$. 
Table (6): Applied irrigation water (IR), ( $\mathrm{mm} /$ period) at different planting date for wheat growth stages.

\begin{tabular}{ccccccc}
\hline PD & IR (\%) & Initial & Develop. & Mid & Late & Seasonal \\
\hline \multirow{3}{*}{$\mathbf{1 5}^{\text {th }}$ Oct. } & $\mathbf{1 0 0}$ & 32.71 & 117.46 & 263.01 & 46.26 & 459.44 \\
\cline { 2 - 7 } & $\mathbf{8 5}$ & 27.80 & 99.84 & 223.56 & 39.32 & 390.52 \\
\cline { 2 - 7 } & $\mathbf{7 0}$ & 22.90 & 82.22 & 184.11 & 32.38 & 321.61 \\
\hline \multirow{3}{*}{$\mathbf{1}^{\text {th }}$ Nov. } & $\mathbf{1 0 0}$ & 17.85 & 114.16 & 304.71 & 57.39 & 494.11 \\
\cline { 2 - 7 } & $\mathbf{8 5}$ & 15.17 & 97.04 & 259.00 & 48.78 & 419.99 \\
\hline \multirow{3}{*}{ 15 $^{\text {th }}$ Nov. } & $\mathbf{7 0}$ & 12.50 & 79.91 & 213.30 & 40.17 & 345.88 \\
\cline { 2 - 7 } & $\mathbf{1 0 0}$ & 17.46 & 108.99 & 358.67 & 67.06 & 552.18 \\
\hline \multirow{3}{*}{ to $^{\text {th Nov. }}$} & $\mathbf{7 0}$ & 14.84 & 92.64 & 304.87 & 57.00 & 469.35 \\
\cline { 2 - 7 } & $\mathbf{1 0 0}$ & 15.66 & 76.29 & 251.07 & 46.94 & 386.52 \\
\cline { 2 - 7 } & $\mathbf{8 5}$ & 13.31 & 102.71 & 354.88 & 63.82 & 534.72 \\
\hline
\end{tabular}

Convert $\mathbf{m m}$ to $\mathrm{m}^{3}=$ water of $\mathbf{m m}$ depth $*$ Area (ha) (10)

- Actual evapotranspiration ETa $=\left(M_{2} \%-M_{1} \%\right) / 100 . d_{b} . D \quad(m m)$ (Doorenbos and Pruitt, 1984)

Where: $\mathbf{M}_{2}$ : moisture content after irrigation $\%$.

$\mathbf{M}_{1}$ : moisture content before irrigation $\%$.

$\mathbf{d}_{\mathbf{b}}$ : specific density of soil .

D : mean depth, mm.

- Water use efficiency WUE = GY / ETa $\quad\left(\mathrm{kg} / \mathrm{m}^{3}\right) \quad$ (Howell et al., 2001) Where: GY: grain yield of wheat, $(\mathrm{kg} / \mathrm{ha})$.

- Irrigation water use efficiency IWUE $=$ GY / IR $\quad\left(\mathrm{kg} / \mathrm{m}^{3}\right) \quad$ (Michael, 1978) Where: IR : seasonal applied irrigation water, $\left(\mathrm{m}^{3}\right)$, (Table 4$)$.

\section{RESULTS AND DISCUSSION}

1. Effect of IR and PD on studied quality parameters and yield production of wheat varieties:

Data in Figures (2), (3), (4), (5), (6) and (7) showed that the studied quality parameters and yield production for all wheat varieties increased with increasing applied irrigation water "IR" at the different planting dates "PD". Also, data revealed that the best of PD for all wheat varieties were $15^{\text {th }}$ Nov. then $1^{\text {th }}$ Nov. The results recorded the same trend for both 
seasons 2014/2015 and 2015/2016. The maximum values of Plant height "PH" cm, numbers of spikes "NS" spikes $/ \mathrm{m}^{2}, 1000$ grain weight "GW" g, grain crude protein content "GCP" \%, gluten content "GC" \%, harvest index "HI" \%, total yield "TY" $\mathrm{Mg} / \mathrm{ha}$, straw yield " $\mathrm{SY}$ " $\mathrm{Mg} / \mathrm{ha}$ and grain yield "GY" $\mathrm{Mg} / \mathrm{ha}$ were $115.24 \mathrm{~cm}, 403.16$ spikes $/ \mathrm{m}^{2}, 53.67 \mathrm{~g}, 15.47 \%$, $31.98 \%, 43.75 \%, 15.42 \mathrm{Mg} / \mathrm{ha}, 9.53 \mathrm{Mg} / \mathrm{ha}$ and $5.89 \mathrm{Mg} / \mathrm{ha} ; 117.39 \mathrm{~cm}$, 418.50 spikes $/ \mathrm{m}^{2}, 56.89 \mathrm{~g}, 15.93 \%, 32.13 \%, 43.93 \%, 15.87 \mathrm{Mg} / \mathrm{ha}, 9.74$ $\mathrm{Mg} / \mathrm{ha}$ and $6.13 \mathrm{Mg} / \mathrm{ha}$ for both seasons respectively, under $\mathrm{IR}=100 \%$, $\mathrm{PD}=15^{\text {th }}$ Nov. and Misr 2 variety treatment. While, the minimum values were $65.04 \mathrm{~cm}, 279.98$ spikes $/ \mathrm{m}^{2}, 23.68 \mathrm{~g}, 8.36 \%, 22.07 \%, 33.75 \%$, $9.65 \mathrm{Mg} / \mathrm{ha}, 6.84 \mathrm{Mg} / \mathrm{ha}$ and $2.81 \mathrm{Mg} / \mathrm{ha} ; 69.27 \mathrm{~cm}, 293.86 \mathrm{spikes} / \mathrm{m}^{2}$, $25.91 \mathrm{~g}, 8.41 \%, 22.19 \%, 34.31 \%, 10.07 \mathrm{Mg} / \mathrm{ha}, 7.12 \mathrm{Mg} / \mathrm{ha}$ and 2.95 $\mathrm{Mg} / \mathrm{ha}$ for both seasons respectively, under $\mathrm{IR}=\mathrm{v}_{0} \%, \mathrm{PD}=15^{\text {th }}$ Oct. and Sakha 94 variety treatment. These results may be attributed to the phasic development stages of wheat are affected by genetic and environmental factors. Planting date had a significant effect on the duration of grain padding. Deficit irrigation decreeing of studied quality parameters and yield production. These results are in harmony with those obtained by (Lak et al., 2013), (Haroun et al., 2012) and (Fazal et al., 2015).

\section{Effect of IR and PD on seasonal actual evapotranspiration of wheat} varieties:

Data in Figures (6) and (7) find out that the seasonal actual evapotranspiration "ETa", $\mathrm{mm}$ for all wheat varieties increased with increasing IR at the different PD. Also, data showed that the ETa for all wheat varieties increased with delay PD. The results recorded the same trend for both seasons 2014/2015 and 2015/2016. The minimum values of ETa were 167.67 and $161.43 \mathrm{~mm}$ for both seasons respectively, under $\mathrm{IR}=70 \%, \mathrm{PD}=15^{\text {th }}$ Oct. and Misr 2 variety treatment. While, the maximum values were 284.34 and $276.82 \mathrm{~mm}$ for both seasons respectively, under $\mathrm{IR}=100 \%, \mathrm{PD}=30^{\text {th }}$ Nov. and Sakha 94 variety treatment. These results agree with (Khalil et al. 2005) and (EL Afandi et al. 2010).

\section{Effect of IR and PD on WUE and IWUE of wheat varieties:}

Data in Figures (6) and (7) illustrated that the water use efficiency "WUE" and irrigation water use efficiency "IWUE" $\mathrm{kg} / \mathrm{m}^{3}$ for all wheat varieties increased with decreasing IR at the different PD. 
Wheat varieties

Sakha 94
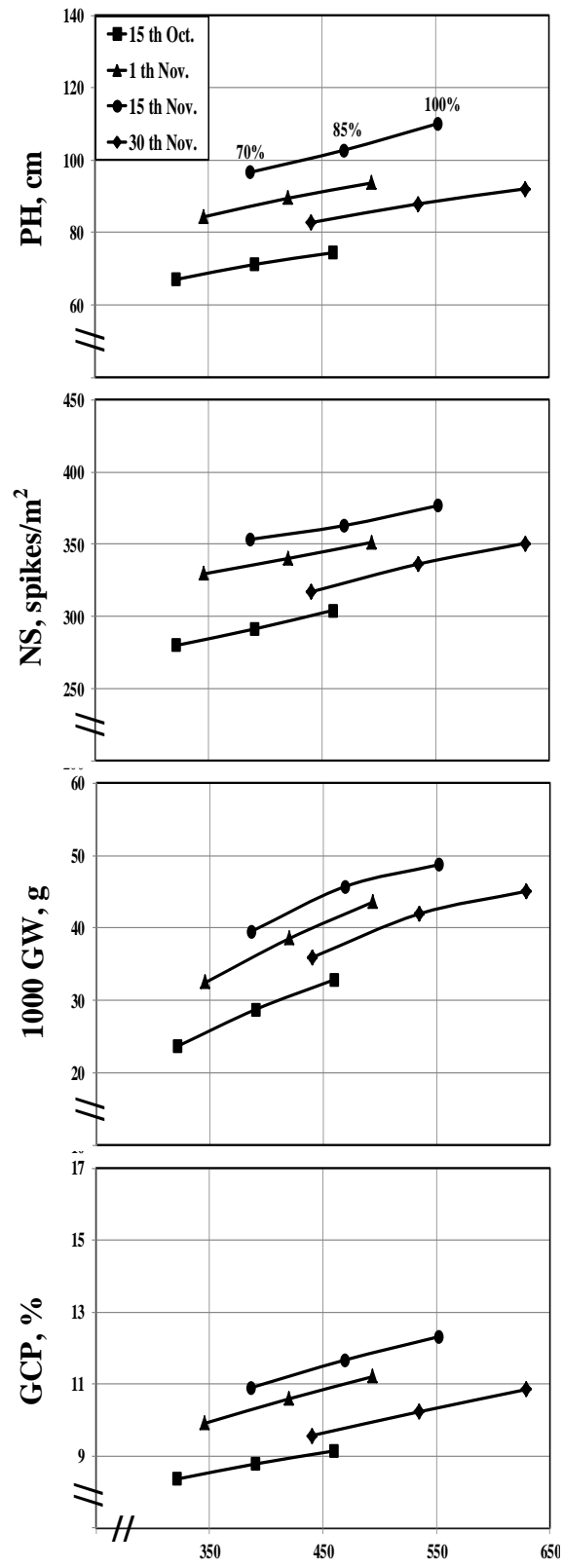

Gemmiza7
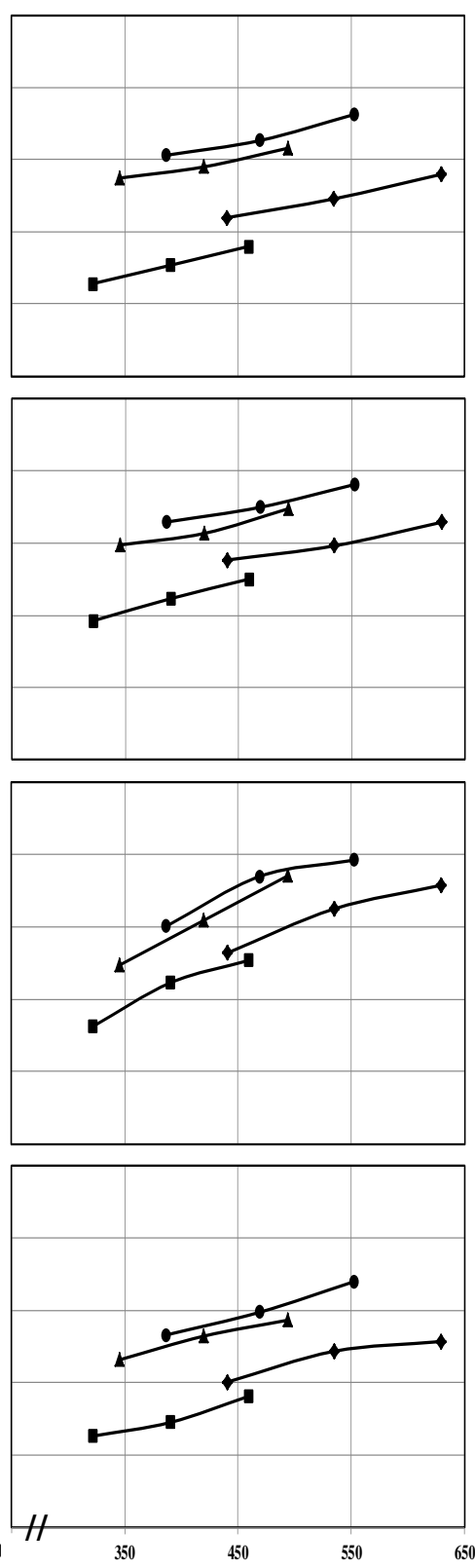

Misr 2
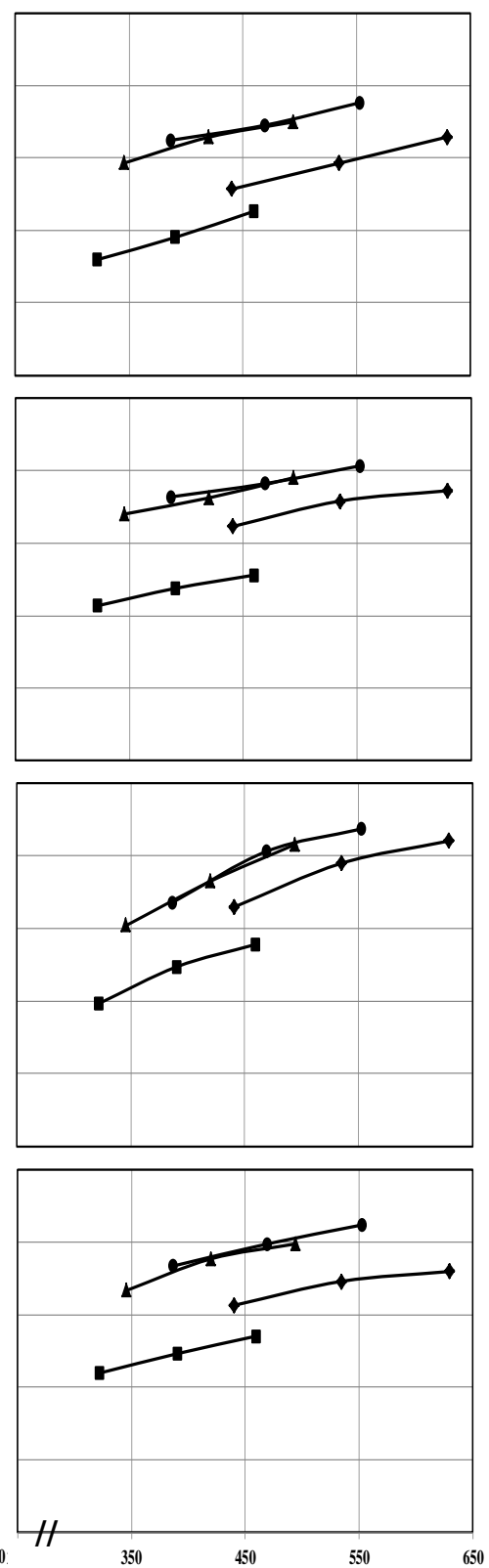

Applied irrigation water (IR), mm

Fig. (2): Effect of applied irrigation water "IR", (mm) and planting date "PD" for wheat crop varieties on Plant height "PH" (cm), numbers of spikes "NS" (spikes/m²), 1000 grain weight "GW" (g ) and grain crude protein content "GCP" (\%) for season 2014/2015. 
Wheat varieties

Sakha 94
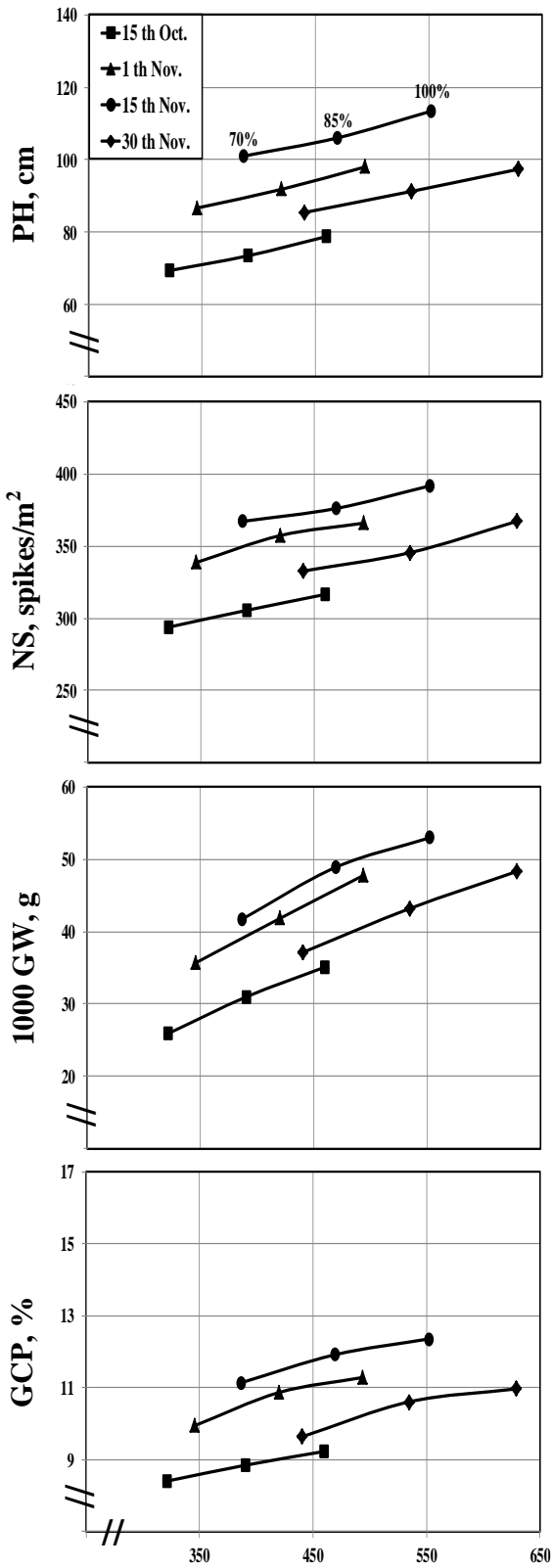

Gemmiza7
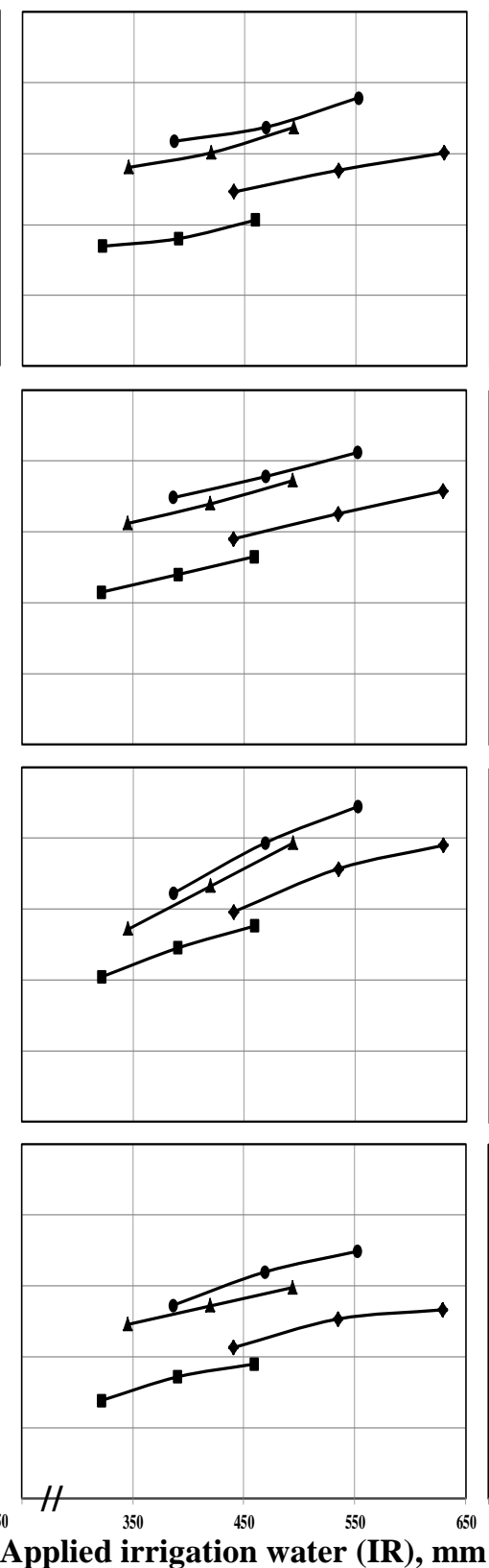

Misr 2
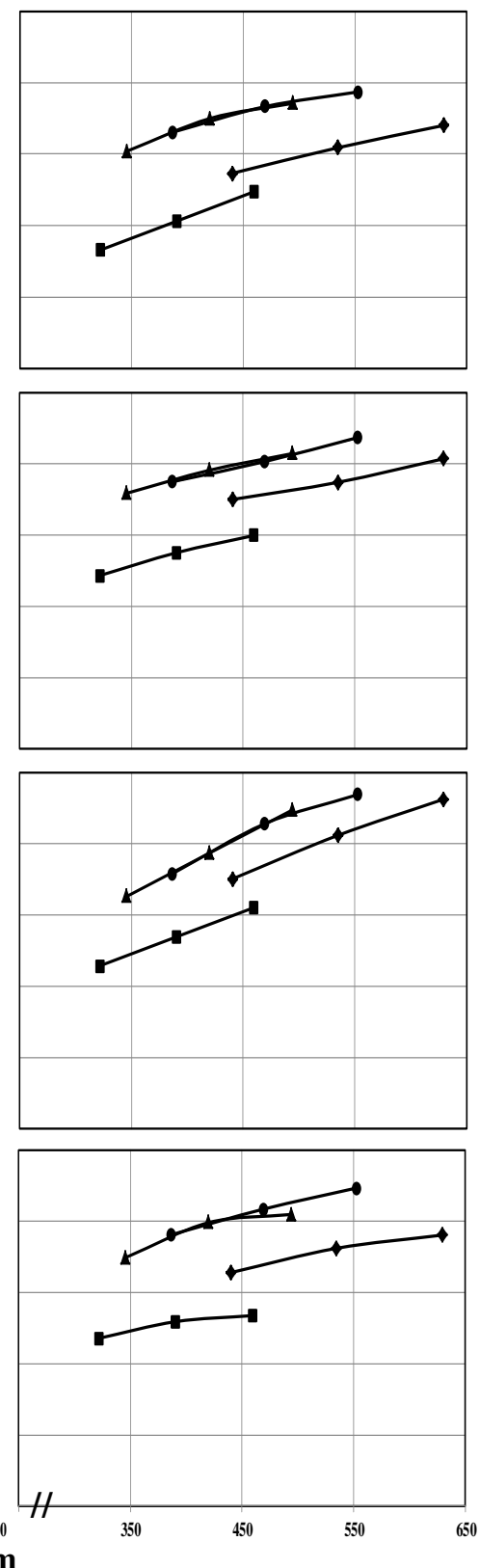

Fig. (3): Effect of applied irrigation water "IR", (mm) and planting date "PD" for wheat crop varieties on Plant height "PH" (cm), numbers of spikes "NS" (spikes/m²), 1000 grain weight "GW" (g ) and grain crude protein content "GCP" (\%) for season 201\%/201 ?. 
Wheat varieties

Sakha 94
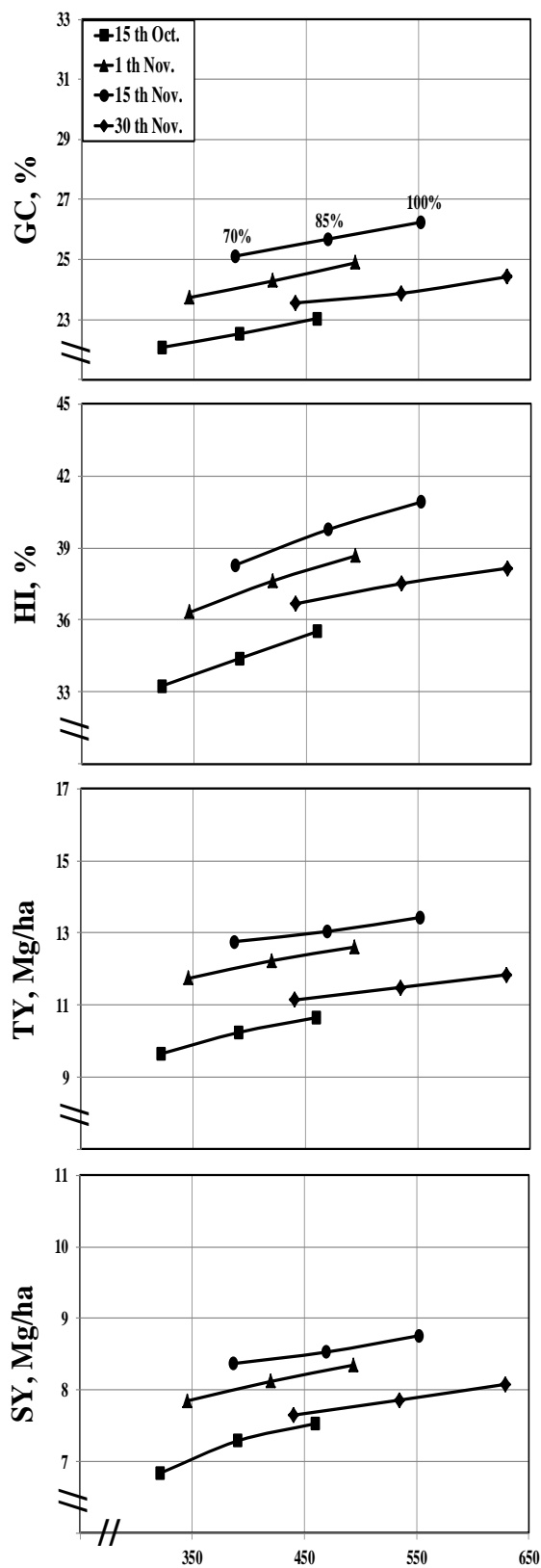

Gemmiza7
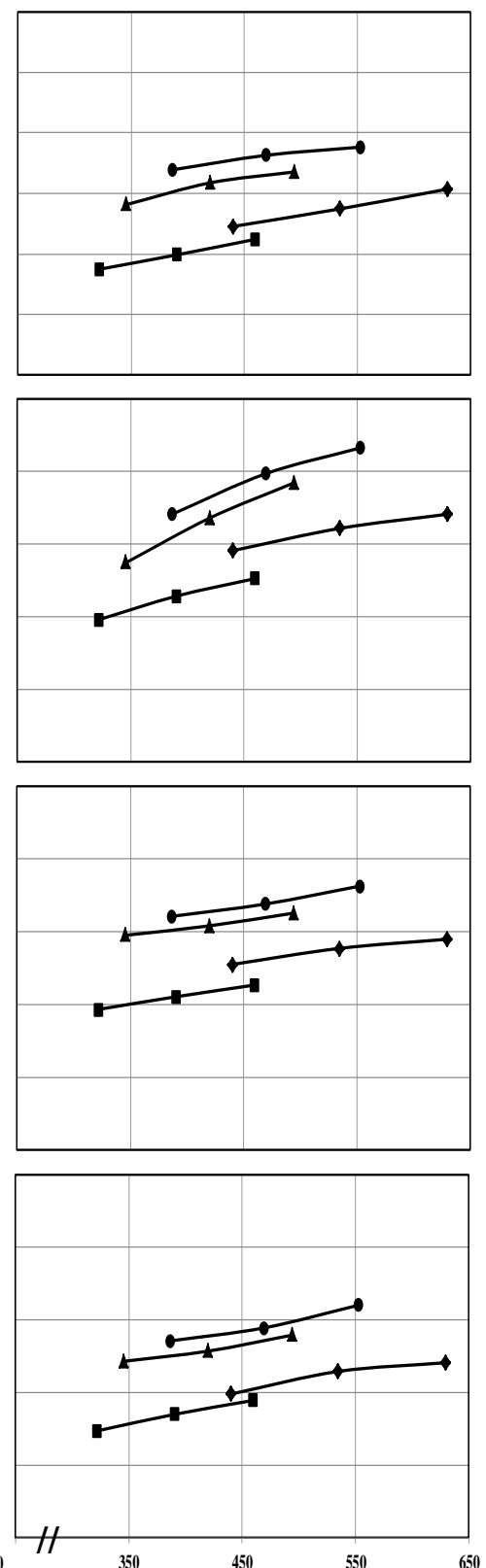

Misr 2
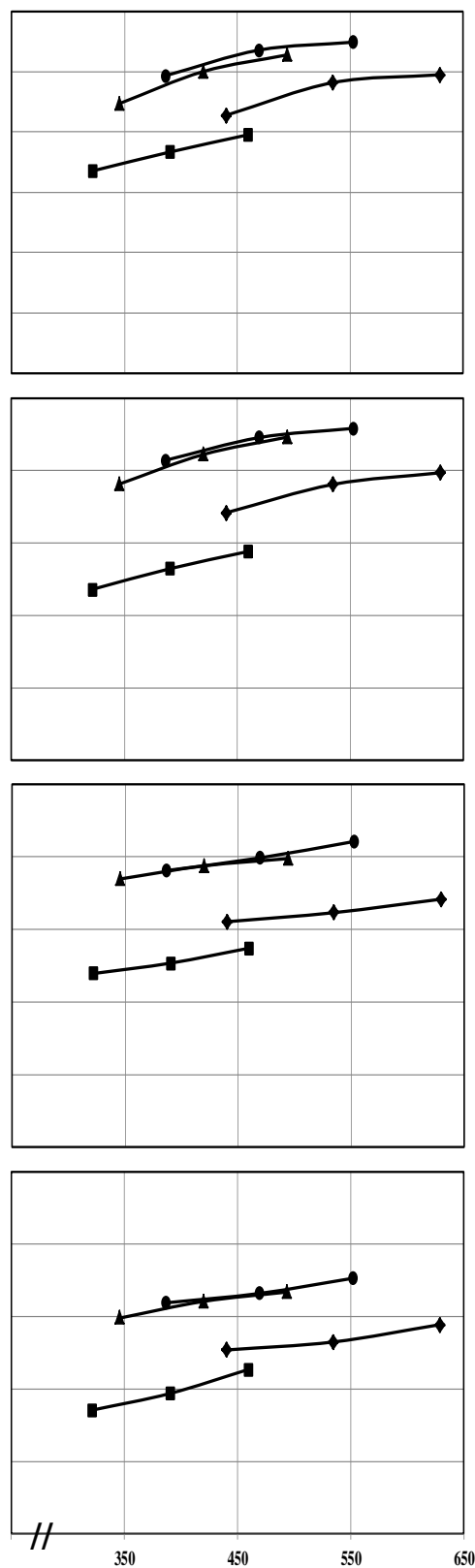

Applied irrigation water (IR), mm

Fig. (4): Effect of applied irrigation water "IR", (mm) and planting date "PD" for wheat crop varieties on gluten content "GC" (\%), harvest index "HI" (\%), total yield "TY" (Mg/ha) and straw yield "SY" (Mg/ha) for season 2014/2015. 
Wheat varieties

Sakha 94
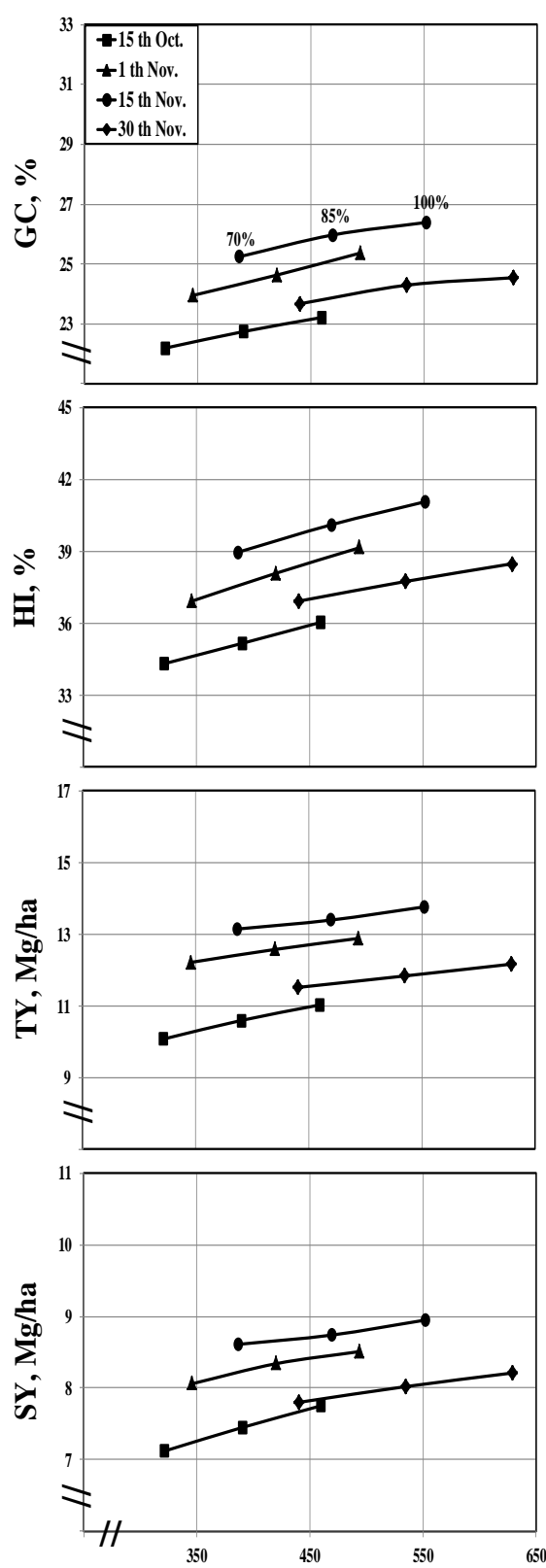

Gemmiza7
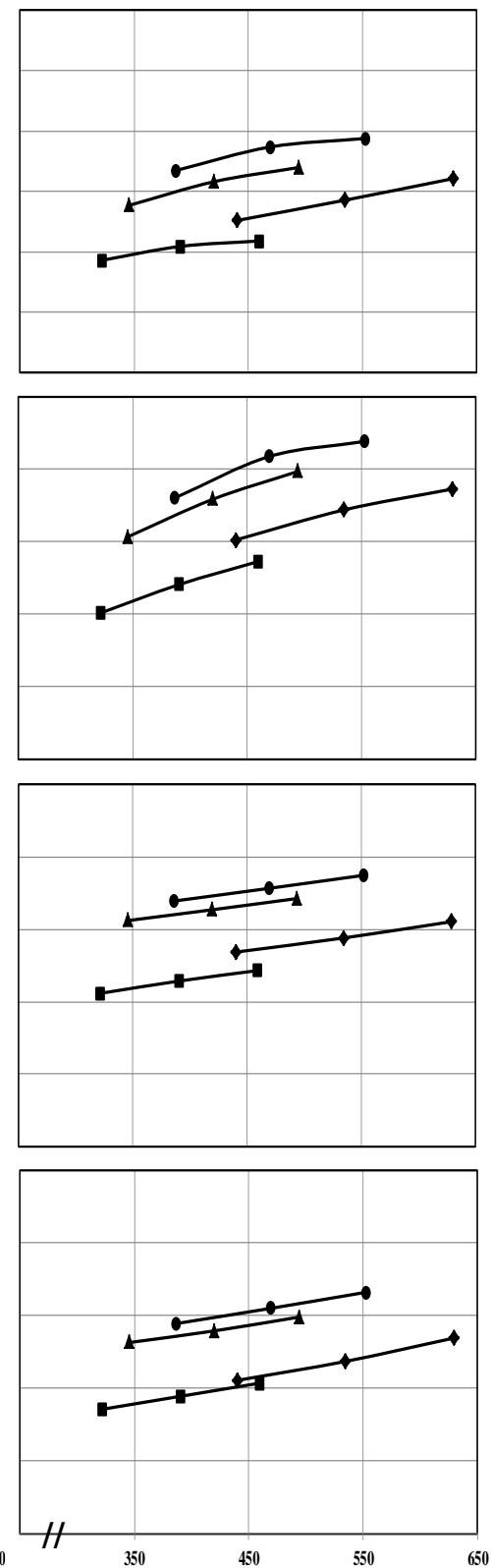

Misr 2
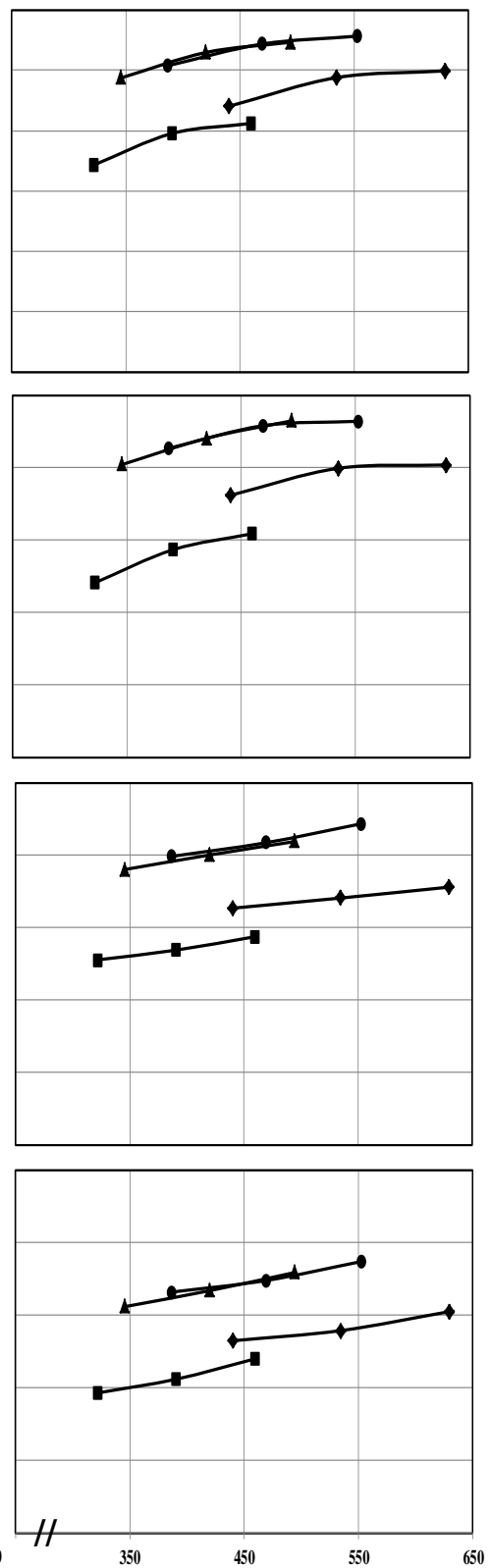

Applied irrigation water (IR), mm

Fig. (5): Effect of applied irrigation water "IR", (mm) and planting date "PD" for wheat crop varieties on gluten content "GC" (\%), harvest index "HI" (\%), total yield "TY" (Mg/ha) and straw yield "SY" (Mg/ha) for season 2015/2016. 
Sakha 94
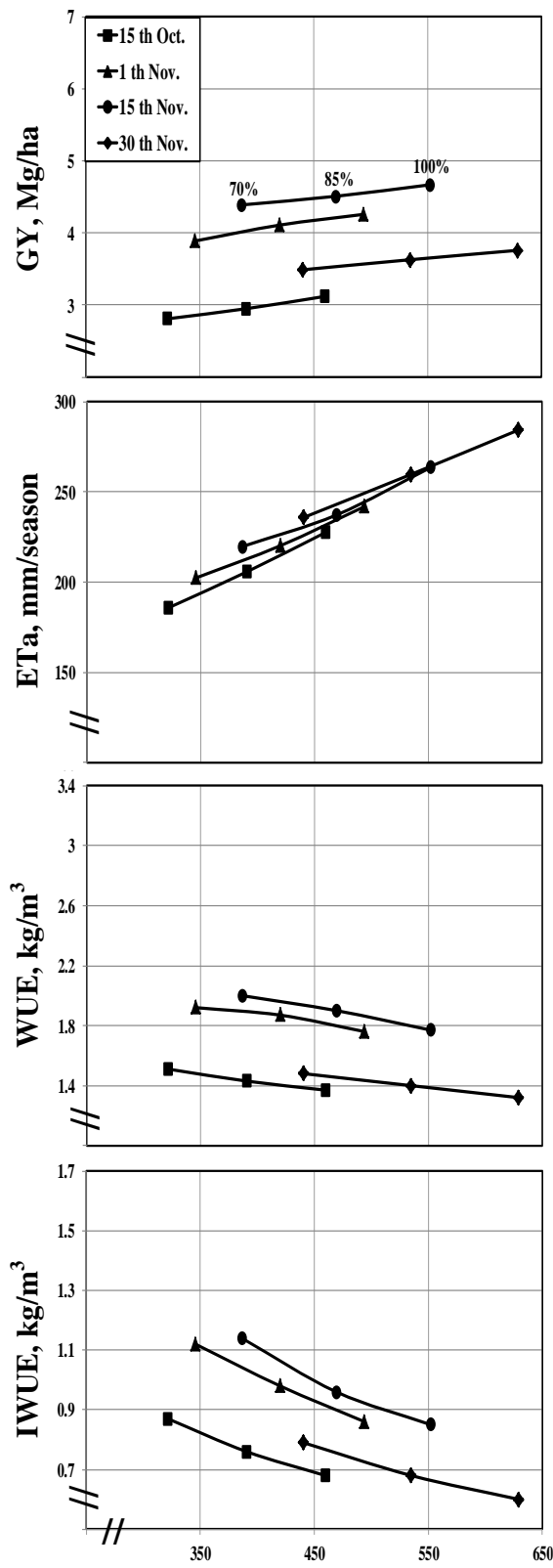

Wheat varieties

Gemmiza7
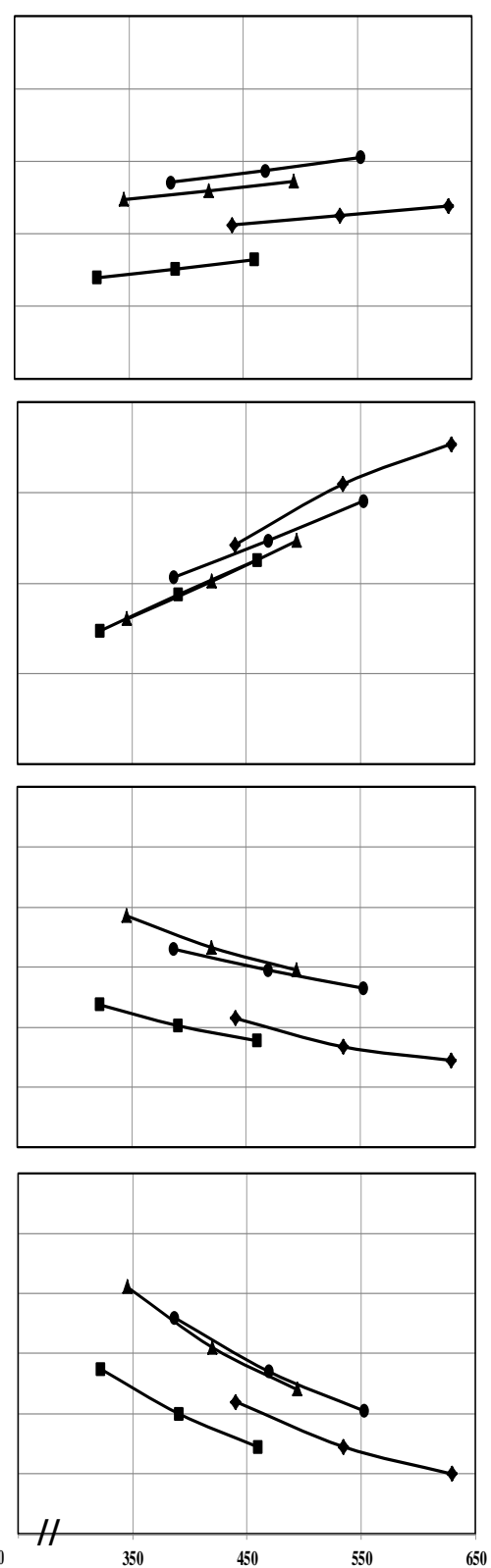

Misr 2
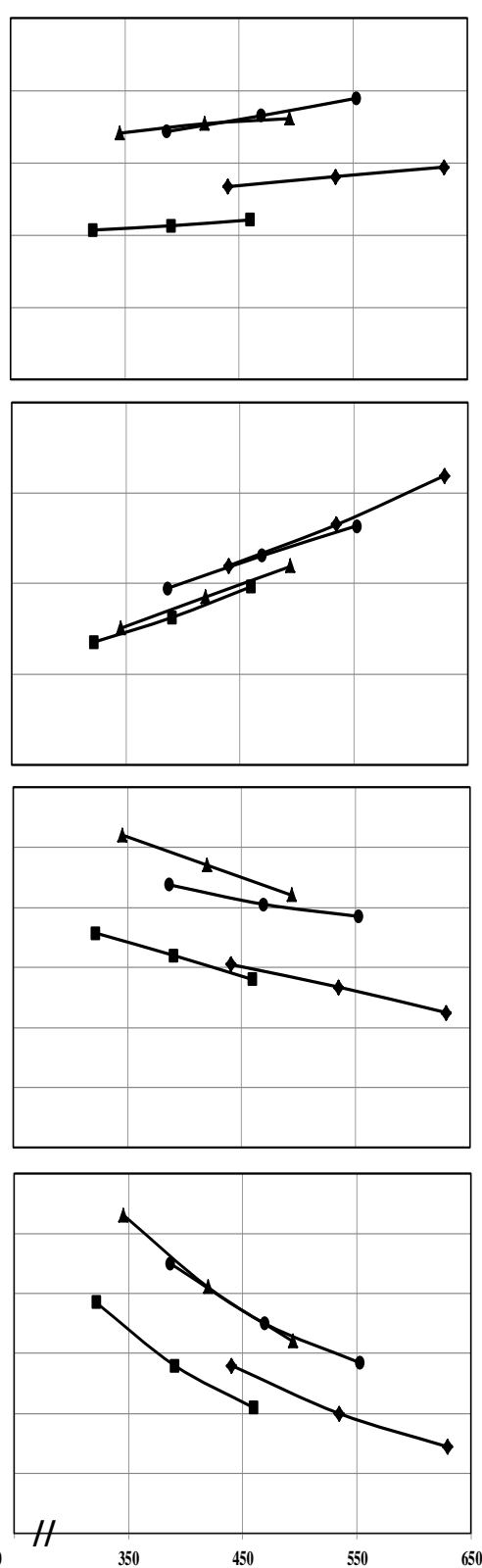

Applied irrigation water (IR), mm

Fig. (6): Effect of applied irrigation water "IR", (mm) and planting date "PD" for wheat crop varieties on grain yield "GY" (Mg/ha), actual evapotranspiration "ETa" (mm/season), water use efficiency "WUE" $\left(\mathrm{kg} / \mathrm{m}^{3}\right)$ and irrigation water use efficiency "IWUE" $\left(\mathrm{kg} / \mathrm{m}^{3}\right)$ for season 2014/2015. 
Wheat varieties

Sakha 94
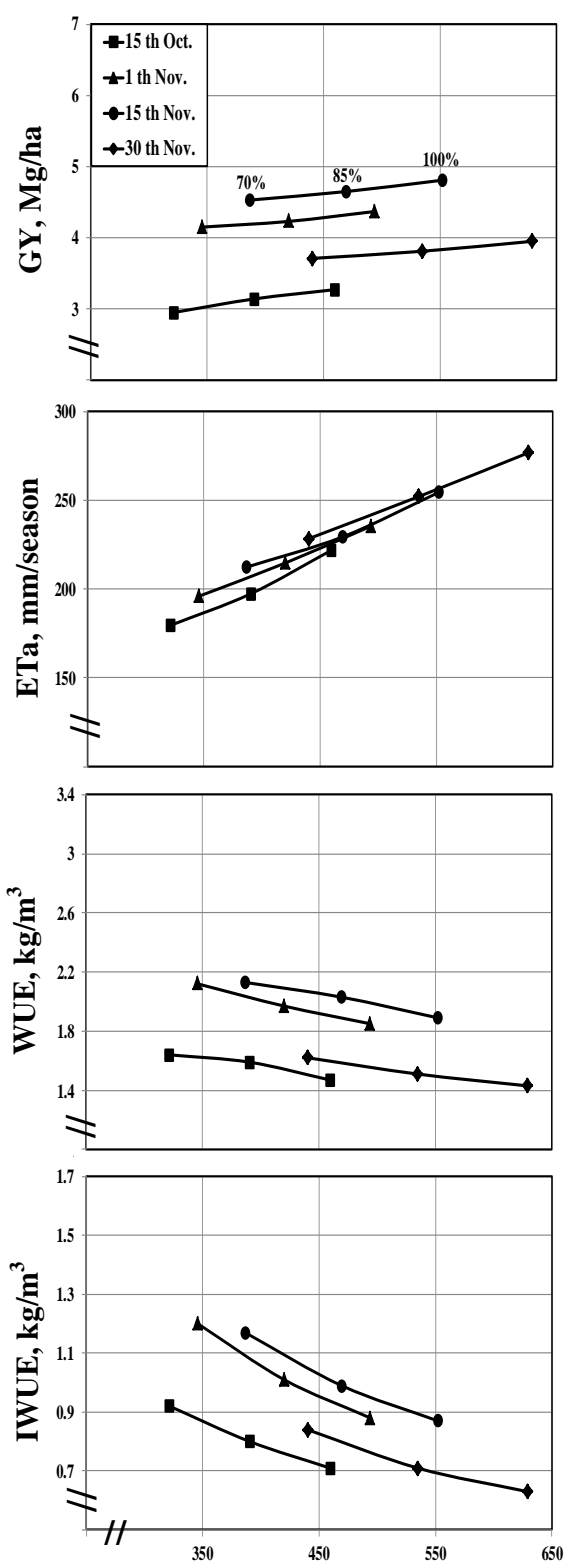

Gemmiza7
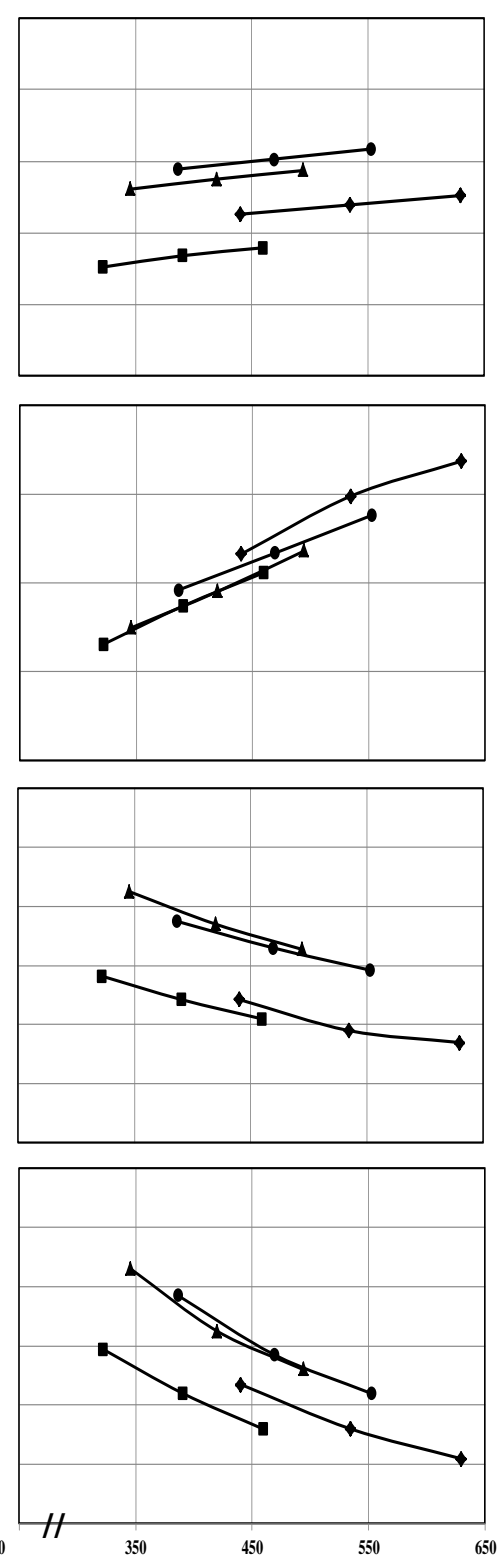

Misr 2
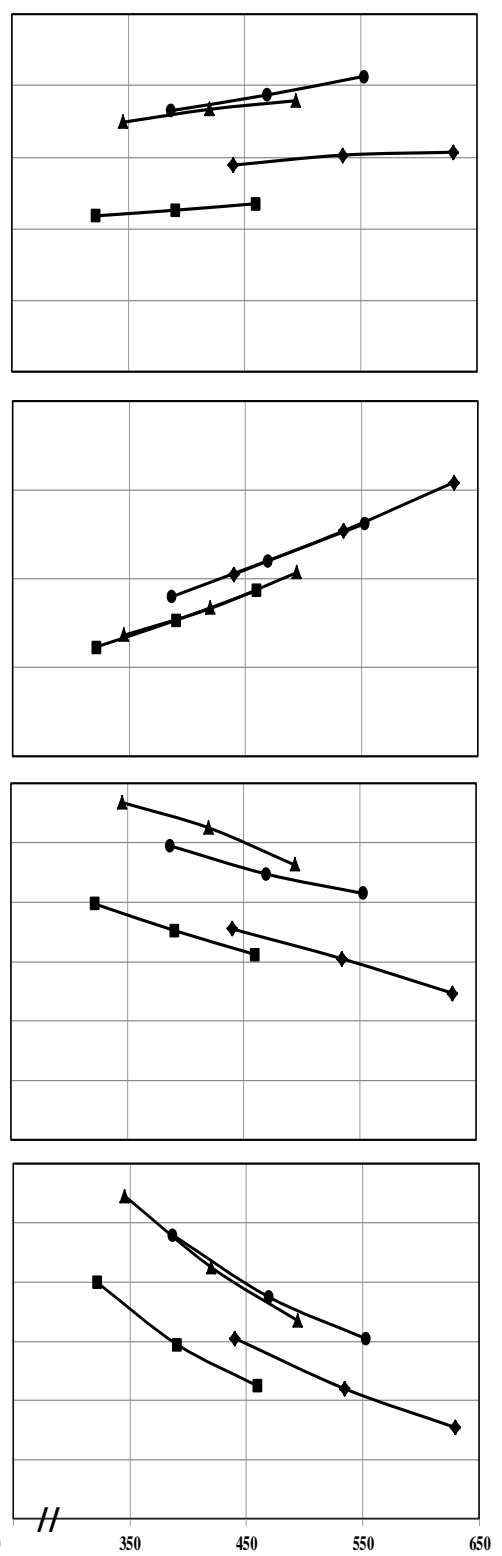

Applied irrigation water "IR", mm

Fig. (7): Effect of applied irrigation water "IR", (mm) and planting date "PD" for wheat crop varieties on grain yield "GY" (Mg/ha), actual evapotranspiration "ETa" (mm/season), water use efficiency "WUE" $\left(\mathrm{kg} / \mathrm{m}^{3}\right)$ and irrigation water use efficiency "IWUE" $\left(\mathrm{kg} / \mathrm{m}^{3}\right)$ for season $2015 / 2016$. 
The maximum values of wheat WUE and IWUE were recorded 3.08 and $1.56 \mathrm{~kg} / \mathrm{m}^{3} ; 3.27$ and $1.59 \mathrm{~kg} / \mathrm{m}^{3}$ for both seasons respectively, under $\mathrm{IR}=70 \%, \mathrm{PD}=1^{\text {th }}$ Nov. and Misr 2 variety treatment. While, the minimum values were 1.32 and $0.60 \mathrm{~kg} / \mathrm{m}^{3} ; 1.43$ and $0.63 \mathrm{~kg} / \mathrm{m}^{3}$ for both seasons respectively, under $\mathrm{IR}=100 \%, \mathrm{PD}=30^{\text {th }}$ Nov. and Sakha 94 variety treatment. Meanwhile, the values of WUE and IWUE under IR=70\%, $\mathrm{PD}=1^{\text {th }}$ Nov. and Misr 2 variety treatment for both seasons were recorded increased significantly by about 21 and $46 \% ; 23$ and $43 \%$ respectively, compared to that under control treatment $\left(\mathrm{IR}=100 \%, \mathrm{PD}=15^{\text {th }}\right.$ Nov. and Misr 2 variety) treatment. These results were similar obtained by (Salem et al. 2006) and (Poraas et al. 2010).

\section{CONCLUSIONS}

The biological yield and studied quality parameters for wheat gave the highest values under $\mathrm{IR}=100 \%, \mathrm{PD}=15^{\text {th }}$ Nov. and Misr 2 variety treatment. While, the seasonal ETa for wheat gave the lowest values under $\mathrm{IR}=70 \%, \mathrm{PD}=15^{\text {th }}$ Oct. and Misr 2 variety treatment. Finally, the values of wheat WUE and IWUE under IR $=70 \%, P D=1^{\text {th }}$ Nov. and Misr 2 variety treatment for both seasons were recorded increased significantly by about 21 and $46 \% ; 23$ and $43 \%$ respectively, compared to that under control treatment ( $\mathrm{IR}=100 \%, \mathrm{PD}=15^{\text {th }}$ Nov. and Misr 2 variety).

So, it is recommended to application $\left(\mathrm{IR}=70 \%, \mathrm{PD}=1^{\text {th }}\right.$ Nov. and Misr 2 variety) treatment to cultivate wheat under El-Qantara Sharq conditions because this treatment could be saved about $37 \%$ of added irrigation water versus yield reduction of wheat about 8 and $10 \%$ for both seasons respectively, compared to that under control treatment $(\mathrm{IR}=1 \cdot 0 \%, \mathrm{PD}=$ $15^{\text {th }}$ Nov.).

\section{REFERENCES}

Allen, R.G.; M. Smith; A. Perrier and L.S. Pereira (1998). Crop Evapotranspiration, guidelines for computing crop water requirements. FAO Irrig. \& Drain. P. No.56, FAO, Rome, Italy: 179.

Amin, G.A.; H.G. Geweifel; M.A. Gomaa; M.A. El-kholy and M.H. Mohamed (2011). Effect of sowing methods and fertilization on yield analysis and grain quality of wheat under new reclaimed sandy soil. J. of Applied Sci. Res. 7(12): 1760-67. 
Anonymous (2010). Statistics of agricultural production. Economic Affairs Sector, Ministry of Agric. and Land Reclamation, Egypt.

Ayers, R.S. and D.W. Westcot (1994). Water Quality for Agric., Irrig. \& Drain. P. No. 29, FAO, Rome, Italy.

Doorenbos, J. and W.O. Pruitt (1984). Crop Water requirements Guidelines for predicting crop requirements. FAO Irrig. \& Drain. P. No.24, FAO, Rome, Italy: 45-90.

El- Afandi, G.; F.A. Khalil and S.A. Ouda (2010). Using irrigation scheduling to increase water productivity of wheat-maize rotation under climate change conditions. Chilean J. of Agric. Res. 70(3):474-484.

El-Kalla, S.E.; A.A. Leillah; M.I. El-Emery and A.M. Kishk (2010). Performance of some wheat (Triticum aestivum L.) cultivars under late sowing in newly reclaimed soils. J. Plant Production, Mansoura Univ., 1(5):689-697.

Fazal, M.; M. Arif; M.T. Jan; K. Ali and M.J. Khan (2015). Influence of sowing dates on phonological development and yield of dual purpose wheat cultivars. Pak. J. Bot., 47(1): 83-88.

Haroun, S.A.; M.A. Abbas; L.M. Abo-Shoba and R.F. El-Mantawy (2012). Effect of planting date on phenology, productivity and flour quality of some wheat cultivars. J. Plant Production, Mansoura Univ., 3 (4): 615 - 626.

Howell, T.A. (2001). Enhancing water use efficiency in irrigated agriculture. Agron. J. Abst., 93: 281 - 289.

Jalota, S.K.; G.B. Singh; S.S. Chahal; S. Ray; P. Bhupinder-Singh and K.B. Singh (2010). Soil texture, climate and management effects on plant growth, grain yield and water use by rain fed maize-wheat cropping system: Field and simulation study. Agric. Water Management, 97(1): 83-90.

Khalil, F.A.; G.A. El-Shaarawy and H.Y. Hasan (2005). Irrigation scheduling for some wheat cultivars through pan evaporation norms and its effect on growth, yield and water use efficiency Fayoum J. Agric. Res. \& develop., 21(1):1-15.

Khokhar, Z.; I. Hussain; B. Khokhar and M. Sohail (2010). Effect of planting dates on yield of wheat genotypes in Sindh. Pakistan J. Agric. Res., 23 (3-4): 103-107. 
Klute, A. (1986). Methods of soil analysis, Part (1). Physical and Mineralogical Methods-Agronomy monograph No. 9 ( $2^{\text {nd }}$ Edition).

Keller, J. and D. Karmeli (1974). Trickle irrigation design parameters. ASAE, 17 (4): 678-684. ASA and SSSA, Madison, WI, USA: 635 660.

Lak, M.; A. Farnia and M. Shaban (2013). Changes in seed yield of wheat (Triticum aestivum L.) cultivars in different sowing dates. Intern. J. Agric. Crop Sci., 5 (8): 861-867.

Michael, A. (1978). Irrigation and theory practice. Vikas Pub. House PVT LTD, New Delihi.

Moussa, A.M. and H.H. Abdel-Maksoud (2004). Effect of soil moisture regime on yield and its components and water use efficiency for some wheat cultivars. Annals Agric. Sci., Ain Shams Univ., 49 (2):515-530.

Ouda, S.A.; S.M. El-Marsafawy; M.A. El-Kholy and M.S. Gaballah (2005). Simulating the effect of water stress and different sowing dates on wheat production in South Delta. J. Applied Sci. Res., 1(3): 268-276.

Page, A.L.; R.H. Miller and D.R. Keeney (1982). Methods of soil analysis, part 2. Chemical and microbiological properties. Amer. Soc. of Agron, Madison, Wisconsin, USA.

Poraas, M.M.; M.A. Mahmoud and N.Y. Osman (2010). Effect of irrigation scheduling and different nitrogen levels on water relation, yield and yield components for wheat crop grown in middle Egypt (Giza region). J. of S. Sci. and Agric. Eng., 1 (1): 49 - 64.

Qamar, M.; A. Shafiullah and S. Makeen (2004). Genetic variability among wheat cultivars and effect of planting date on grain and straw yield under double cropping zone of Northern areas of Pakistan. Sarhad J. of Agri. 20(1): 99-102.

Salem, N.R.; G.A. El-Shaarwy and H.H. Abdel-Maksoud (2006). Performance of two bread wheat cultivars under different irrigation regimes. Egypt. J. Appl. Sci., 21(12): 60-82.

Seleiman, M.; M. Ibrahim; S. Abdel-Aal and G. Zahran (2011). Effect of sowing dates on productivity, technological and rheological characteristics of bread wheat. J. Agro. Crop Sci., 2(1): 1- 6. 
Seleem, S.A. and S.M. Abd El-Dayem (2013). Response of some wheat cultivars to nitrogen fertilizer levels. J. Plant Production, Mansoura Univ., 4(5): 721 - 731.

Snedecor, G.W. and W.G. Cochran (1989). Statistical methods, $8^{\text {th }}$ Ed., Iowa State Univ. Press, Iowa. USA: 476.

Yassin, M.I. and H.F. Kittani (2009). A multivariate analysis of the effects of planting dates on productivity of some wheat genotypes. J. Sci. Tech., 10 (2): 46-59.

\section{الملخص العربيى}

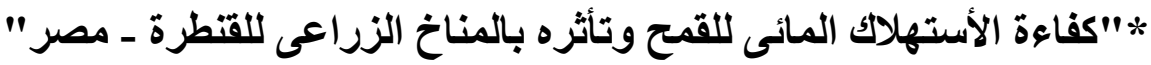

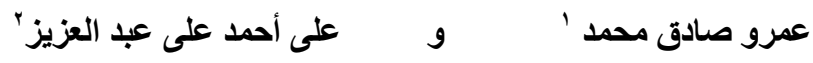

أجريت هذه التجربة فى منطقة القنطرة شرق بمحافظة الأسماعيلية - جمهورية مصر العربية

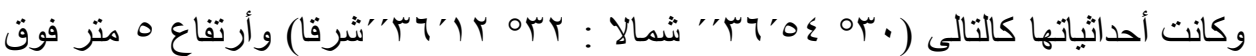

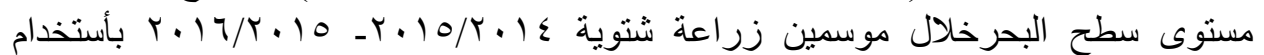

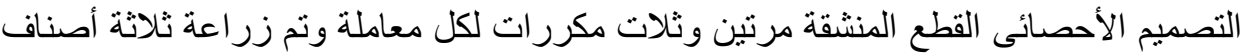

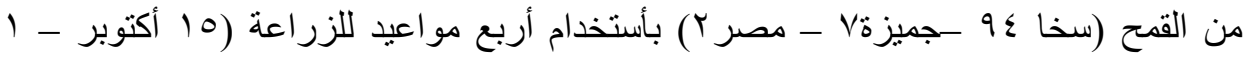

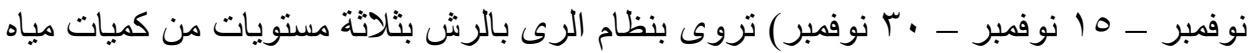

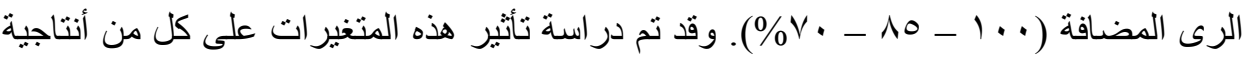
وقياسات الجودة لمحصول القمح وكذلك الأستهلاك المائى الفعلى وكفاءة الأستهلاك المك المائى

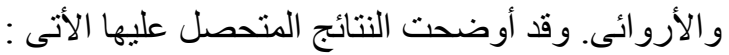

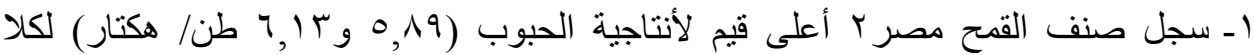

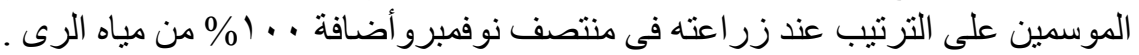

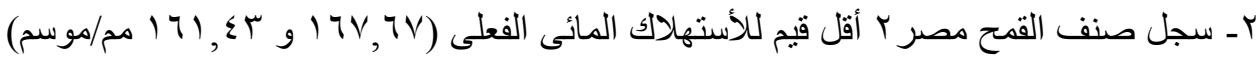

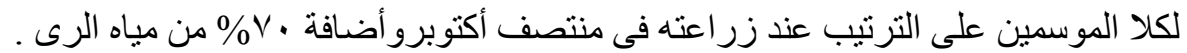

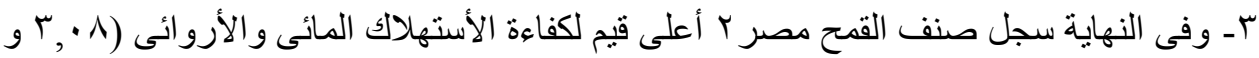

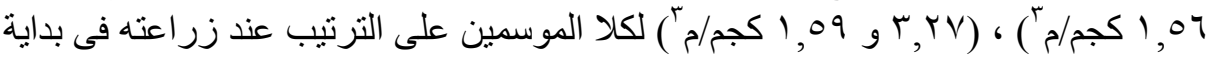

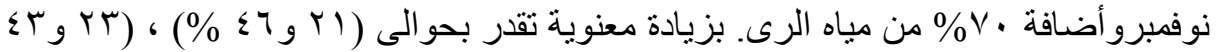

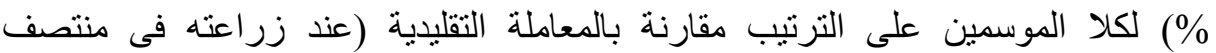

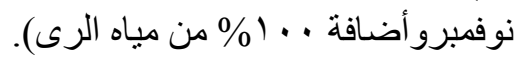

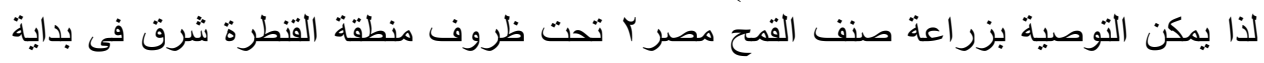

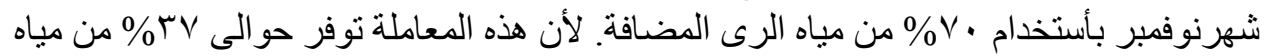

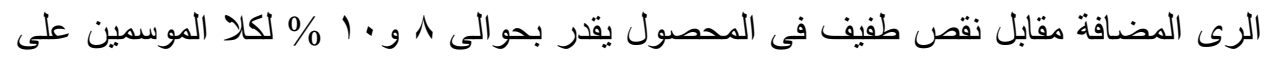

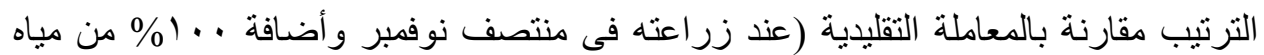

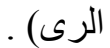

اوץ - قسم كيمياء وطبيعة الأراضى - مركز بحوث الصحراء. 